\title{
Vegetable Cultivation in Uttarakhand Hills: Viewing Through a Gender Lens
}

\author{
Sonu Fartyal and Surya Rathore* \\ Department of Agricultural Communication \\ G. B. Pant University of Agriculture \& Technology \\ Pantnagar - 263145 (Uttarakhand), India
}

\begin{abstract}
Gender is a social unhierarchical ordering of institutions into strongly classified words of men and women. It is used for studying the role of men and women in a society. Women form the backbone of agriculture in India, comprising the majority of agricultural labourers and have been contributing not only in terms of physical output but also in terms of quality and efficiency. They along with men are actively involved in vegetable cultivation activities, yet their active role is not countable. The present study was carried out on extent of participation of farmers and farm women in vegetable cultivation in Uttarakhand hills of India. The study was undertaken in two villages namely, Rousil and Ladkhora. Purposive sampling was followed for selection of the district, villages and respondents whereas blocks were selected through chit method of Simple Random Sampling. Analytical research design was used to meet the objectives set forth for the study. The data were collected through pretested structured interview schedule. The findings showed that the majority of labour activities related to vegetable cultivation were performed by women. The total time spent by men was $8.31 \mathrm{~h}$ per day and women spent $14.31 \mathrm{~h}$ per day on vegetable cultivation activities. Although women start work on the farm at a very early age, they still have little access and control over property, both moveable and immovable.
\end{abstract}

Keywords: Extent of participation, gender, vegetable cultivation

\section{INTRODUCTION}

The progress and prosperity of a country truly depends on both; men and women who are complementary to each other. Men and women work together in farm activities, but participation of women is higher than men. Women are the majority of the world's agricultural producers; worldwide women produce more than $50 \%$ of the food that is grown (FAO, 1995). The rural women are very active in cultivation, dairy, fisheries, crop processing and other allied areas. Women's role in agriculture is critical (globally they are responsible for at least $50 \%$ of food produced) and their work in agriculture is crucial to the provision of an adequate food supply for their household. Women make up 51\% of the agricultural labour force worldwide. According to FAO (1995), women tend to focus on crops for household consumption and to sell any excess while men cultivate crops primarily for sale, leading to a disproportionate portion. The roles and status of women in agriculture and rural areas vary widely by region, age, ethnicity and social class and changing rapidly in

Corresponding author: suryarathore@gmail.com 
some parts of the world. Policy- makers, donors and development practitioners need information and analysis reflect the diversity of the contributions women make and the specific challenges they are confronted with in order to make gender-aware decisions about the sector (http://www.fao.org/gender/en/agri-e.htm).

\section{Vegetable Cultivation in India}

India is an agriculture based country. Hundreds of fruits and vegetables are grown in all parts of India. Horticulture contributes $29.5 \%$ to Gross Domestic Product originating from agriculture from $8.5 \%$ of cultivable land (Singh et al., 2004) and has proved beyond doubt its potentiality for gainful diversification. One of the significant developments is that horticulture has moved from rural confine to commercial production, and this changing scenario has boosted up the horticulture industry. Several initiatives taken by the Government and other stakeholders also have great impact on the development of horticulture in terms of increased production, productivity and also availability of horticultural crops. India is the second largest producer of vegetables next to China with $2.8 \%$ of total cropped area under vegetables (Kumar et al., 2011). With a production of less than 20 million tons before the country got independence in the year 1947, vegetable production has increased manifold to 133.7 million tons in 2009-10. The area under vegetable cultivation has increased from 5593 thousand hectare in 1991-92 to 7985 thousand hectare in $2009-10$. The overall growth rate of $2.08 \%$ in area, $1.64 \%$ in productivity and $3.72 \%$ in total production has been achieved during the last five years (Kumar et. al., 2011).

\section{Vegetable Cultivation in Uttarakhand}

Uttarakhand has about $13 \%$ of its geographic area under cultivation out of which $80 \%$ of the land does not have assured irrigation facilities thus making agricultural crops totally dependent on vagaries of nature. However, in these dry lands fruit plants can be grown successfully and off - season vegetable cultivation in irrigated land. At present, the area under fruits is 179.3 thousand hectares whereas the area under vegetables is almost half i.e. 85.8 thousand hectare with much higher production of 1030.9 thousand million tons (Kumar et al., 2011). Table 1 reveals that over the years, the area, production and productivity of vegetables has increased in spite of land fragmentation. Despite small holdings, most of the farmers have opted for a shift in production from low value food grains like wheat, paddy, ragi to high commercial crops particularly vegetable and pulses (Uttarakhand State Perspective and Strategic Plan 2009 - 2027).

Table1. Area Production and Productivity of Vegetables in Uttarakhand

\begin{tabular}{lllllc}
\hline \multicolumn{1}{c}{ Year } & $\mathbf{1 9 9 1 - 9 2}$ & $\mathbf{2 0 0 1 - 0 2}$ & $\mathbf{2 0 0 8 - 0 9}$ & $\mathbf{2 0 0 9 - 1 0}$ & $\mathbf{2 0 1 0 - 1 1}$ \\
\hline $\begin{array}{l}\text { Area } \\
\text { (000 ha) }\end{array}$ & 57.1 & 93.8 & 81.8 & 82.57 & 85.8 \\
$\begin{array}{l}\text { Production } \\
\text { (000 MT) }\end{array}$ & 617.6 & 737.3 & 1077.6 & 997.285 & 1030.9 \\
$\begin{array}{l}\text { Productivity } \\
\text { (MT/ha) }\end{array}$ & 10.8 & 7.9 & 13.2 & 12.1 & 12.0 \\
\hline
\end{tabular}

Source: Kumar et al., 2011 


\section{Gender in vegetable cultivation in India}

In India, agriculture is a highly gender sensitive sector with $75.38 \%$ of all women work force engaged in agriculture. Within agriculture, 94\% of women in crop cultivation are in cereal production and other crops i.e. $14 \%$ in vegetable production and horticulture, while $3.72 \%$ are engaged in fruits, nuts, beverages and spice crops (Singh and Sengupta, 2009). Vegetables show a high share of women workers $(39.13 \%)$. Women are a key factor in vegetable cultivation. They contribute between $46 \%$ and $65 \%$ of all hours on growing and farming of vegetables of all kinds (Joy, 1980). Both men and women work in vegetable cultivation with women farmers spending most of their time in activities like planting, harvesting, weeding, hoeing, transplanting while men are involved in operations like irrigation, harvesting and packing (Grover and Sethi, 2007).

\section{Gender in vegetable cultivation in Uttarakhand}

Majority of Uttarakhand agriculture is rainfed and is subsistence in nature, there is not much surplus for the market. This leads to low incomes and unstable incomes, which in turn lead to a sizeable out - migration of men to other places in search of employment. Only women are left in the hills and the role of women in household economy begins. In agriculture, there is gender inequality in Uttarakhand hills as women work force in agriculture constitutes to about $80 \%$. The fact is well supported by Shiva (1991) that in Indian Himalayas, a pair of bullock works 1064 hours, a man 1212 hours and woman 3485 hours in a year on a one hectare farm. In hills where the environment is harsh, slopes are deep, scattered and scarce land, women devote major chunk of their daily routine for various farm operations thus shouldering load of drudgery. Women along with men are actively involved in vegetable cultivation activities, yet their active role is not countable. Very few studies in agriculture have been done in the state keeping the gender perspective in view, but no study has been conducted in this regard with reference to vegetable cultivation. So, there is an urgent need to analyze the roles of men and women farmers in vegetable cultivation and to ascertain and assure the areas where women are still far from enjoying the minimum privileges, access to resources and decision making.

This study would also help the extension personnel to understand the grey areas of training and extension services in vegetable cultivation in the hills of Uttarakhand for men and women farmers separately. It has been widely recognized that unless women's potential is properly developed, no transformation and economic development is possible. Therefore, both for consideration of sustainability and equity, it is essential that vegetable farming research and extension should be more gender centered reflecting the role of women and men as vegetable farmers. Considering the gender perspective of vegetable cultivation in the hills, the present study was conducted with an objective to find out the extent of participation of men and women farmers in vegetable cultivation and gender variation in access to and control over resources.

\section{METHODOLOGY}

Uttarakhand, is the $27^{\text {th }}$ state of union of India lying in between $28^{\circ} 42^{\prime}$ and $31^{0} 28^{\prime}$ north latitude and $77^{0} 35^{\prime}$ to $81^{\circ} 50^{\prime}$ eastern latitude comprising 13 districts. Out of 13 districts of the state, Nainital district was selected purposively as it represents high hills of Uttarakhand and is highest producer of vegetable. The common vegetables grown in this district are potatoes, lentil, onion, chillies, peas, radish and cauliflower. Nainital district comprises eight 
blocks. Bhimtal and Dhari blocks were selected through simple random sampling using chit method. Out of these blocks, village Rousil in Bhimtal block and village Ladkhora in Dhari block were selected purposively due to the reason that these villages were the highest vegetable producing villages in each of these blocks and village Rousil is located in close proximity to Krishi Vigyan Kendra (Farm Science Centre), Jeolikot which comes under the jurisdiction of Govind Ballabh Pant University of Agriculture \& Technology, Pantnagar to which the researcher belongs. A sample of 98 respondents was selected purposively i.e. one man and one woman from all those households whose primary occupation was agriculture. In all, there were 53 houses in village Rousil and 77 houses in village Ladkhora. Out of these, only 28 and 21 households in villages Rousil and Ladkhora were selected respectively. The criteria for selection of respondents were:

> Families whose primary occupation was vegetable cultivation.

$>$ One man and one woman from each of the households were selected.

For the present study, the extent of participation has been referred to as division of labour and time allocation of men and women farmers in vegetable cultivation. The tools used for data collection were interview schedule and informal observation along with focused group discussions. Respondents were intensively observed by the researcher for a couple of months from early morning till evening along with personal interview.

\section{RESULTS AND DISCUSSION}

\section{Background information of the respondents}

Majority of the respondents fell in the middle age group of $31-51$ years. Gender distribution indicates that majority of the women farmers were from young and middle age group whereas men were from middle and older age groups. This indicates that women farmers start their job at an earlier age as compared to men famers. The income of the households was of medium level with US\$365.33 to 940.05 per annum. There was no separate income of men and women, it belonged to the household. Majority of these households had $5-10$ family members in nuclear families. More than half of the households had marginal land holding of less than one hectare with medium level of farm equipment such as bullock drawn plough which was used for land preparation and rest of the field operations were done by locally made hand tools. Mixed cropping was followed by majority of the households and the major vegetables grown during rabi season (October - February) were spinach, cabbage and potatoes whereas major kharif (July - October) vegetables grown by the respondents were radish, carrot, coriander, beetroot, French bean, tomato, chillies, brinjal, bottle gourd, onion and garlic, chilies, potato and cucumber were the vegetables which were grown in zaid (March - June) season.

\section{Division of labour in vegetable cultivation}

It is an overall pattern in which women are allotted to a set of gender roles and men another set. It also refers to the extent and the daily division of labour in identifying the individual workloads or capacities of women and men or the extent to which farmers and farm women are involved in vegetable cultivation. There were total 16 vegetable cultivation activities, which are performed either individually by men or women, men and hired labour, women and hired labour or only by hired labour. For the convenience of discussion, these 16 vegetable cultivation operations have been divided into four groups, namely; (1) field 
preparation, (2) nursery management, (3) after care and agronomic practices and (4) harvesting and post-harvest handling practices.

Table 2. Distribution of respondents on the basis of division of labour in field preparation

\begin{tabular}{|c|c|c|c|c|c|c|c|}
\hline S. No. & $\begin{array}{l}\text { Activities/ } \\
\text { Tasks }\end{array}$ & $\operatorname{Men}(n=49)$ & $\begin{array}{l}\text { Women } \\
(n=49)\end{array}$ & Jointly & $\begin{array}{l}\text { Men and } \\
\text { Hired } \\
\text { labour } \\
\text { (Men) }\end{array}$ & $\begin{array}{l}\text { Women } \\
\text { and Hired } \\
\text { labour } \\
\text { (Men) }\end{array}$ & $\begin{array}{l}\text { Hired } \\
\text { labour } \\
\text { (Men) }\end{array}$ \\
\hline 1 & $\begin{array}{l}\text { Land } \\
\text { preparation }\end{array}$ & $\begin{array}{l}22 \\
(44.89 \%)\end{array}$ & $\begin{array}{l}36 \\
(73.46 \%)\end{array}$ & $\begin{array}{l}12 \\
(12.24 \%)\end{array}$ & $\begin{array}{l}11 \\
(22.44 \%)\end{array}$ & $\begin{array}{l}7 \\
(14.28 \%)\end{array}$ & - \\
\hline 2 & $\begin{array}{l}\text { Ploughing } \\
\text { of Field }\end{array}$ & $\begin{array}{l}38 \\
(77.55 \%)\end{array}$ & - & - & $\begin{array}{l}9 \\
(18.36 \%)\end{array}$ & - & $\begin{array}{l}2 \\
(4.08 \%)\end{array}$ \\
\hline 3 & $\begin{array}{l}\text { Cleaning of } \\
\text { field }\end{array}$ & $\begin{array}{l}28 \\
(57.14 \%)\end{array}$ & $\begin{array}{l}47 \\
(95.91 \%)\end{array}$ & $\begin{array}{l}4 \\
(4.08 \%)\end{array}$ & $\begin{array}{l}3 \\
(6.12 \%)\end{array}$ & - & - \\
\hline 4 & $\begin{array}{l}\text { Leveling of } \\
\text { field }\end{array}$ & $\begin{array}{l}41 \\
(83.67 \%)\end{array}$ & $\begin{array}{l}18 \\
(36.73 \%)\end{array}$ & $\begin{array}{l}13 \\
(13.26 \%)\end{array}$ & $\begin{array}{l}9 \\
(18.36 \%)\end{array}$ & - & - \\
\hline
\end{tabular}

Cursory of Table 2 reveals that in the area of field preparation, the participation of women farmers was highest in cleaning of field (95.91\%) and land preparation (73.46\%) whereas $83.67 \%$ and $77.55 \%$ men farmers were involved in ploughing and leveling of field respectively. The reasons for this could be that ploughing in hill agriculture is done by bullock drawn plough, rest all the other activities are performed by hand tools which are made locally. Traditionally, it has been the men domain to manage and use the bullocks so this activity was not at all performed by women farmers. There is a glass ceiling which prevents the women from even attempting to do male dominated activities. Only two respondents hired labour and $18.36 \%$ men farmers did ploughing with the help of hired labour which were also men from the neighbouring country Nepal. In Nepal, the trans boundary migration rate is high $(70 \%)$ which is explained by the proximity to Indian border (Sherpa, 2010).

Table 3. Distribution of respondents on the basis of division of labour in Nursery management

\begin{tabular}{|c|c|c|c|c|c|c|c|}
\hline S. No. & $\begin{array}{l}\text { Activities/ } \\
\text { Tasks }\end{array}$ & $\begin{array}{l}\text { Men } \\
(n=49)\end{array}$ & $\begin{array}{l}\text { Women } \\
(n=49)\end{array}$ & Jointly & $\begin{array}{l}\text { Men and } \\
\text { Hired } \\
\text { labour }\end{array}$ & $\begin{array}{l}\text { Women } \\
\text { and Hired } \\
\text { labour } \\
\text { (Men) }\end{array}$ & $\begin{array}{l}\text { Hired } \\
\text { labour } \\
\text { (Men) }\end{array}$ \\
\hline 1 & $\begin{array}{l}\text { Selection of } \\
\text { seeds }\end{array}$ & $49(100 \%)$ & $\begin{array}{l}13 \\
(26.53 \%)\end{array}$ & - & - & - & - \\
\hline 2 & $\begin{array}{l}\text { Raising } \\
\text { nursery for } \\
\text { seedling }\end{array}$ & $\begin{array}{l}11 \\
(22.44 \%)\end{array}$ & $\begin{array}{l}44 \\
(89.79 \%)\end{array}$ & $\begin{array}{l}10 \\
(10.20 \%)\end{array}$ & - & - & - \\
\hline 3 & $\begin{array}{l}\text { Seed } \\
\text { Treatment } \\
\text { before } \\
\text { Sowing }\end{array}$ & $2(4.08 \%)$ & $49(100 \%)$ & - & - & - & - \\
\hline 4 & Sowing & $\begin{array}{l}37 \\
(75.51 \%)\end{array}$ & $3(6.12 \%)$ & $\begin{array}{l}24 \\
(24.48 \%)\end{array}$ & - & - & - \\
\hline 5 & Transplanting & $\begin{array}{l}28 \\
(57.14 \%)\end{array}$ & $\begin{array}{l}45 \\
(91.83 \%)\end{array}$ & $8(8.16 \%)$ & - & - & - \\
\hline
\end{tabular}


Table 3 depicts that all the men farmers under study were involved in deciding as to which variety of seeds to use for their crops whereas the tedious jobs such as seed treatment before sowing and transplanting were performed by $100 \%$ and $91.8 \%$ of the women farmers. Yet, another task of nursery raising for seedling was done by $89.8 \%$ women. This activity of nursery raising requires patience and since time immemorial women have been nurturing their children at home and also associated with raising the young ones of animals that they have at home. In the study area, more than half $(51.2 \%)$ of the women farmers had animal husbandry as their subsidiary occupation whereas men were busy with business or service along with agriculture. One important feature to be noted is that no labour was hired by the farmers for nursery management activities, it was done by men and women farmers separately or jointly.

Table 4. Distribution of respondents on the basis of division of labour related to after care and agronomic practices

\begin{tabular}{|c|c|c|c|c|c|c|c|}
\hline $\begin{array}{c}\text { S. } \\
\text { No. }\end{array}$ & $\begin{array}{l}\text { Activities/ } \\
\text { Tasks }\end{array}$ & Men $(n=49)$ & $\begin{array}{l}\text { Women } \\
(n=49)\end{array}$ & Jointly & $\begin{array}{l}\text { Men and } \\
\text { Hired } \\
\text { labour } \\
\text { (Men) }\end{array}$ & $\begin{array}{l}\text { Women } \\
\text { and Hired } \\
\text { labour } \\
\text { (Men) }\end{array}$ & $\begin{array}{l}\text { Hired } \\
\text { labour } \\
\text { (Men) }\end{array}$ \\
\hline 1 & Hoeing & $\begin{array}{l}26 \\
(53.06 \%)\end{array}$ & $\begin{array}{l}34 \\
(69.38 \%)\end{array}$ & $\begin{array}{l}12 \\
(12.24 \%)\end{array}$ & $\begin{array}{l}17 \\
(34.69 \%)\end{array}$ & $\begin{array}{l}9 \\
(18.36 \%)\end{array}$ & - \\
\hline 2 & Weeding & $\begin{array}{l}11 \\
(22.44 \%)\end{array}$ & $\begin{array}{l}43 \\
(87.75 \%)\end{array}$ & - & - & 6 & - \\
\hline 3 & Irrigation & $\begin{array}{l}49 \\
(100 \%)\end{array}$ & $\begin{array}{l}32 \\
(65.30 \%)\end{array}$ & - & - & - & - \\
\hline 4 & $\begin{array}{l}\text { Plant } \\
\text { protection } \\
\text { measures }\end{array}$ & $\begin{array}{l}38 \\
(77.55 \%)\end{array}$ & $\begin{array}{l}13 \\
(26.53 \%)\end{array}$ & $\begin{array}{l}11 \\
(11.22 \%)\end{array}$ & - & - & - \\
\hline
\end{tabular}

It is clear from Table 4 that $100 \%$ of men farmers were irrigating their fields on their own and $77.6 \%$ were responsible for using plant protection measures whereas women dominated tasks were hoeing $(69.4 \%)$, weeding $(87.8 \%)$ and to some extent irrigation $(65.3 \%)$ and plant protection measures $(26.3 \%)$. In the area of after care and agronomic practices, except hoeing and weeding, no hired labour was used. Adhikari (2003) reported that in vegetable cultivation, women were involved in manure carrying \& dispersing, seedling, planting, weeding. However, men were involved in land preparation, harvesting and irrigation. There are some gender stereotyped roles in our society which explains that certain roles are attributed to a particular gender only.

Table 5. Distribution of respondents on the basis of division of labour in harvesting and post-harvest handling practices

\begin{tabular}{|c|c|c|c|c|c|c|c|}
\hline S. No. & $\begin{array}{l}\text { Activities/ } \\
\text { Tasks }\end{array}$ & $\begin{array}{l}\text { Men } \\
(n=49)\end{array}$ & $\begin{array}{l}\text { Women } \\
(n=49)\end{array}$ & Jointly & $\begin{array}{l}\text { Men and } \\
\text { Hired } \\
\text { labour } \\
\text { (Men) }\end{array}$ & $\begin{array}{l}\text { Women } \\
\text { and Hired } \\
\text { labour } \\
\text { (Men) }\end{array}$ & $\begin{array}{l}\text { Hired } \\
\text { labour } \\
\text { (Men) }\end{array}$ \\
\hline 1 & Harvesting & $\begin{array}{l}17 \\
(34.69 \%)\end{array}$ & $\begin{array}{l}14 \\
(28.57 \%)\end{array}$ & $\begin{array}{l}38 \\
(38.77 \%)\end{array}$ & $\begin{array}{l}11 \\
(22.44 \%)\end{array}$ & $\begin{array}{l}18 \\
(36.73 \%)\end{array}$ & - \\
\hline 2 & $\begin{array}{l}\text { Post } \\
\text { harvesting }\end{array}$ & $\begin{array}{l}33 \\
(67.34 \%)\end{array}$ & $\begin{array}{l}26 \\
(53.06 \%)\end{array}$ & $\begin{array}{l}16 \\
(16.32 \%)\end{array}$ & $\begin{array}{l}9 \\
(18.36 \%)\end{array}$ & $\begin{array}{l}14 \\
(28.57 \%)\end{array}$ & - \\
\hline 3 & Marketing & $\begin{array}{l}49 \\
(100 \%)\end{array}$ & $\begin{array}{l}5 \\
(10.20 \%) \\
\end{array}$ & - & - & - & - \\
\hline
\end{tabular}


Perusal of Table 5 reveals that $100 \%$ men farmers were doing the marketing of their produce whereas only five women farmers were doing this work that too in the absence of their men counterpart. Activities like harvesting of vegetables and post-harvest handling were performed by majority of the men farmers and more than half of the women farmers whereas $16.3 \%$ of them were performing this work jointly. Still, more than one fourth $(28.6 \%)$ of the women did this activity along with hired men labour and $18.4 \%$ men farmers were hiring labour for post -harvest handling of vegetables.

Thus, it was revealed from data that majority of time consuming and tedious activities such as land preparation, raising nursery for seedling, seed treatment before sowing, transplanting, hoeing, weeding were performed by women respondents. Only three activities irrigation, ploughing of field and marketing of produce were male dominated. And other activities were also reported to have been performed jointly by men and women, men and hired labour, women and hired labour. Data also revealed that there was negligible role of hired labour. It was due to the reason that most of the tedious activities were carried out by women and they do not want to spend money for hiring labour. One very significant feature of hill agriculture in Uttarakhand which is to be brought into light is that the hired labour here refers to men who come from neighbouring country Nepal.

The findings of the present study are in line with those of (Varma and Goldey, 1997), (Singh et al., 2004) and (Sekabambe and Odong, 2008) who reported that majority of farm activities were performed by women and other activities were carried out by men and women jointly.

\section{Time allocation in vegetable cultivation activities}

It refers to the actual involvement of men and women in terms of time spent on different vegetable cultivation activities. Both the respondents were inquired about the time spent by $\mathrm{him} / \mathrm{her}$ on various vegetable cultivation activities. There were total 16 activities pertaining to vegetable cultivation. The average time spent on vegetable cultivation was recorded in minutes per day on each activity.

Table 6. Distribution of respondents on the basis of average time spent on vegetable cultivation (minutes/day)

\begin{tabular}{clcc}
\hline S. No & Activities/Tasks & Men $(\mathbf{n}=\mathbf{4 9})$ & Women $(\mathbf{n}=\mathbf{4 9})$ \\
\hline 1. & Land preparation & 23.85 & 98.32 \\
2. & Selection of seeds & 10.06 & 08.00 \\
3. & Ploughing of fields & 25.40 & - \\
4. & Cleaning of field & 18.93 & 132.80 \\
5. & Leveling of field & 15.36 & 12.30 \\
6. & Raising nursery for seedling & - & 34.91 \\
7. & Seed treatment before sowing & - & 17.55 \\
8. & Sowing & 10.36 & 10.65 \\
9. & Transplanting & 10.44 & 105.55 \\
10. & Hoeing & 20.36 & 128.68 \\
11. & Weeding & 10.24 & 135.44 \\
12. & Irrigation & 30.77 & 25.05 \\
13. & Plant protection measures & 24.97 & 18.21 \\
14. & Harvesting & 31.48 & 29.30 \\
15. & Marketing & 245.79 & 35.40 \\
16. & Post harvesting & 20.61 & 66.56 \\
& Average minutes /day & $\mathbf{4 9 8 . 6 2}$ & $\mathbf{8 5 8 . 7 2}$ \\
& Average hours/day & $\mathbf{8 . 3 1}$ & $\mathbf{1 4 . 3 1}$ \\
\hline
\end{tabular}


Table 6 shows that women farmers spent much more time daily in vegetable cultivation activities than men. According to the data, average time spent by men was 498.62 minutes/day ( 8.31 hours/ day) as against 858.72 minutes/ day (14.31 hours/ day) by women famers on vegetable cultivation activities.

For activities such as land preparation, average time spent by women farmers was 98.32 minutes/ day, selection of seeds 08.00 minutes/ day and cleaning of field 132.80 minutes/ day. The women farmers spent on an average 40 to 80 minutes/ day in different activities such as leveling of field, raising nursery for seedling, seed treatment and sowing. Some of the activities like transplanting, average time spent by women were 105.55 minutes/ day, hoeing 128.68 minutes/ day, weeding 135.44 minutes/ day and irrigation 25.05 minutes/day. Last four activities such as plant protection measures; average time spent by women farmers was 18.21 minutes/day, harvesting; 29.30 minutes/day, marketing; 35.40 minutes/day and post harvesting 66.56 minutes/ day.

The data revealed that for activities like land preparation; average time spent by men farmers was 23.85 minutes per day, selection of seeds 10.06 minutes/ day, cleaning of field 25.40 minutes/day. Men spent on an average 30 to 70 minutes/ day in different activities such as leveling of field, sowing, transplanting hoeing and weeding. For the last four activities such as irrigation, average time spent by men was 30.77 minutes/day, plant protection measures 24.97 minutes/day, harvesting 31.48 minutes/day, post harvesting 20.61 minutes/day except marketing where the time spent was 245.79 minutes/day.

Hence, women spent much more time daily in vegetable cultivation activities than men. In hills women devote more time in vegetable cultivation. From early morning to till evening they go to the field and spent 14-15 hours in vegetable cultivation activities. These findings are in compliance with the findings of several other researchers, who reported devotion of more time by women farmers than men farmers in farm activities (Kaur and Punia, 1986), (Shikka and Swarup, 1988) and (Negi and Rawat, 2010). The reasons for this can be attributed to subsidiary occupation of men farmers in business and service and some men also migrate to urban areas of Uttarakhand in search of alternate sources of income whereas women remain at home and take care of the household work, animals, collecting fire wood and vegetable cultivation activities in the hills. Women in Uttarakhand hills spend as long as 17 to 18 hours a day in doing household and other works including farming, fuel wood collection, animal husbandry etc. On the other hand, the men folk are involved in leisure activities like playing cards, liquor consumption etc. (Yadav, 2009).

\section{Gender variation in access to and Control over resources}

This section deals with the variations that existed in the hill agriculture with reference to access to and control over the various resources between the two genders. Access refers to one of the five levels of equality which is important in the process of women's development. Women's achievement for equality of access to resources and services is seen as an objective for women's equality and in similar manner women's mobilization to achieve equality of access is an element of the process of empowerment. Control means the ability to direct or influence events so that one's own interests are protected. The women's equality and empowerment framework recognizes women's equality of control with men as the most important or "highest" aspect of women's development where women ensure that resources and benefits are distributed so that both women and men get equal shares. The resources in question here are land, credit, farm inputs, farm equipments and sale of farm produce. 
Table 7. Distribution of respondents according to the basis of access to and control over resources $(\mathrm{N}=98)$

\begin{tabular}{rlccc}
\hline $\begin{array}{r}\text { S. } \\
\text { No. }\end{array}$ & \multicolumn{1}{c}{ Category } & Men & Women & Jointly \\
\hline 1. & Land & 98 & - & - \\
2. & Credit & $\begin{array}{c}(100 \%) \\
98\end{array}$ & - & - \\
& $\begin{array}{c}(100 \%) \\
66\end{array}$ & 10 & 22 \\
Inputs(seeds, & $(67.34 \%)$ & $(10.20 \%)$ & $(22.44 \%)$ \\
& $\begin{array}{l}\text { fertilizers, } \\
\text { pesticides) }\end{array}$ & 18 & - & - \\
Farm & $\begin{array}{l}\text { equipments } \\
\text { (jeep, tractor) }\end{array}$ & $(18.36 \%)$ & 12 & 52 \\
5. & $\begin{array}{l}\text { Sale of farm } \\
\text { produce }\end{array}$ & 34 & $(12.24 \%)$ & $(52.06 \%)$ \\
\hline
\end{tabular}

Table 7 very clearly depicts that there was $100 \%$ control of men on land and credit. This was due to the fact that land is a highly productive resource and this continues to be largely in the name of men famers. There was total control of men over inputs like seeds, fertilizers and pesticides, farm equipments like jeep, tractor and sale of farm produce which was $67.34 \%$, $18.36 \%$ and $34.69 \%$ respectively. The possible reasons lie in Indian patrilineal descend system where control over land was mainly ascribed to men due to the higher status credited to them by society. To own land is a matter of power. The more land, the more power, so why would men like to share the power with women? On the other hand, women in general do not care about power or access to land as long as the family is intact. Women's access to land is largely through inheritance, and inheritance is governed largely by customs which are highly biased against women. States also have inheritance laws that vary according to region and religion. While these are better than customs, they are still biased against women. There is a large gap between women's rights in law and disinheritance in practice, for example women 'voluntarily' surrendering their inherited share of land to their brothers in return for the security that the latter ostensibly provide them. And finally, even where women legally own land, there is a yawning gap between ownership and actual managerial control over the land.

On the contrary, women had very little control over inputs (10.20\%) and sale of farm produce (12.24\%). Although women start work on farm at a very early age, they still have very little access and control over property, both moveable and immovable. In general, women farmers participate in all the activities of vegetable production and men farmers possess the means of production and hold the income. The findings of the present study are in conformity with that of (Rothchild, 1987), (Agarwal, 1994), (Adhikari, 2005), (Devkota, 2006) and (Mikalista, 2010) who also reported that women had limited access to resources; the actual control remained in the hands of men. Devkota (2006) conducted a study on access to and control over household resources and revealed that women's participation to control income generated from cereal crops, cash crops and large animals were almost none. In study area, less number of farmers possessed farm equipments (only 18 out of 98) as hill agriculture is mostly devoid of these modern equipments and uses indigenous implements. 


\section{CONCLUSIONS}

The present study concludes that the majority of labour intensive activities related to vegetable cultivation were performed by women except ploughing, plant protection measures and marketing which were performed by men. Land preparation, hoeing, weeding, harvesting and post harvesting were done by women and hired labour. According to the study, the average time spent by men was 8.31 hours/day as against 14.31 hours/day spent by women on vegetable cultivation activities. Thus, it could be revealed from the study that women's work in hills is strenuous and time consuming. Though most of the activities in vegetable cultivation were carried out by women still they had only limited access to resources and only limited control over those they can access due to the impact of patriarchy and dominance of their men counterparts over these resources. These kinds of gendered gaps in access to resources and services are a type of obstacle to women's development. There should be capacity building workshops for both to understand the gender dynamics and fill the gender gaps that exist in the society, which can be hindrance to overall development.

\section{REFERENCES}

Adhikari, R. (2005). Effects of Commercialisation and Feminisation of Vegetable farming on social status of women in an urban fringe of western Nepal. Himalayan Journal of Soiology and Anthrology. 3, 86-105.

Agarwal, B. (1994). Gender and Command over property: A critical gap in economic analysis and policy in south Asia. World Development. 22, 1455-1478.

Devkota, D. (2006). Access to and control over household resources: A consistency check using gender analysis and household survey data. Nepal Agriculture Research Journal. 7, 98102.

FAO (1995) Women Agriculture and Rural Development in the Near East, A Synthesis Report of Near East Region, Beijing, China

Grover, I and Seth, N (2007) Mapping out gender dynamics of farming systems of Haryana Journal of Social Science, 14, 281-288.

Kaur, S and Punia, P. (1986). Performance and satisfaction from household work. Indian Journal of Home Science. 4, 215-220.

Kumar, B; Mistry, N.C.; Singh, B and Gandhi, C.P. (2011) Indian Horticulture Database 2011, National Horticulture Board, Ministry of Agriuclture Government of India, New Delhi

Mikalista, S. (2010). Gender specific constraints affecting technology use and household food security in western province of Kenya. African Journal of Food, Agriculture, Nutrition and Development. 10, 2324-2343.

Negi, V. and Rawat, L.S. (2010). Work participation and role of gender in village ecosystem, Central Himalaya. Environ. We Int. J. Sci. Tech. 5, 137-146. 
Rothchild, C.S. (1987). Farming systems and gender issues: Implications for agricultural training and projects. In international course on Rural Extension, Workshop III, 1989. Published by International Agriculture Centre, Wageningen, The Netherlands.

Sekabambe, C.K. and Odong, T. (2008). Division of labour in nakati (Solanum aethiopicam) production in central Uganda. African Journal of Agricultural Research. 3, 400-406.

Sherpa, D (2010) Labour migration and remittances in Nepal. International Centre for Integrated Mountain Development, Kathmandu.

Shikka, B.K. and Swarup, R. (1988). Role of women in Hill farming: A study of Himachal Pradesh. Abstract: International Conference on Appropriate technologies for farm women, Nov. 30 - Dec. 6, ICAR, New Delhi.

Shiva, V (1991) Most farmers on India are Women, Food and Agriculture Organisation New Delhi India.

Singh, P; Jhamtani, A; Bhadauria, C Srivastava, R; Singh, R and Singh, J. (2004). Participation of women in Agriculture. Indian Journal of Extension Education. 30, 23-27.

Uttarakhand StatePerspective and Strategic Plan 2009-2027. Watershed Management Directorate Dehradun 288p.

Varma, S.K. and Goldey, P. (1997). Gender roles in farming systems in Haryana state, India: Implications for food security. International Famine Centre, 13p.

Yadav, K (2009). Information dissemination in Uttarakhand: Problems and prospects [0n line]. Accessed on 7.11.2012]. Available at

http://www.agropedia.iitk.ac.in/content/information-dissemination-uttarakhand-problemsand-prospects

http://www.fao.org/gender/en/agri-e.htm. [Accessed on 22-4-11] 